\title{
Recent atmospheric injections of nuclear debris: Fallout from the 16 October 1980 nuclear explosion
}

\author{
L. A. BurChField and P. K. Kuroda \\ Department of Chemistry, University of Arkansas, Fayetteville, Arkansas 72702, U.S.A.
}

(Received 31 May, 1982: Accepted 14 December, 1982)

\begin{abstract}
The concentrations of ${ }^{89} \mathrm{Sr}$ and ${ }^{90} \mathrm{Sr}$ in a total of 117 samples of individual rain and snow collected at Fayetteville $\left(36^{\circ} \mathrm{N}, 94^{\circ} \mathrm{W}\right)$, Arkansas, were determined radiochemically during the period between September 1979 and August 1981. A spectacular increase in the concentration of ${ }^{90} \mathrm{Sr}$ in the atmospheric precipitation was observed during the month of March 1981, approximately 5 months after the 25 th Chinese nuclear test of 16 Octuber 1980. A complicated pattern of variation of the ${ }^{89} \mathrm{Sr} /{ }^{90} \mathrm{Sr}$ ratio in rain observed after this nuclear explosion is interpreted in terms of the general theory of radioactive fallout based on the two-compartment model of the atmosphere, taking into consideration the fact that the nuclear debris released into the atmosphere at Lop Nor $\left(40^{\circ} \mathrm{N}, 90^{\circ} \mathrm{E}\right)$, China, is known to travel eastward and circle the world more than once.
\end{abstract}

\section{INTRDUCTION}

Since 1964, the government of China has been maintaining its nuclear weapons test program at Lop Nor $\left(40^{\circ} \mathrm{N}, 90^{\circ} \mathrm{E}\right)$, in the Takla Makan Desert of China's Sinkiang Province, which is located almost on the opposite side of the world from our laboratories at Fayetteville $\left(36^{\circ} \mathrm{N}, 94^{\circ} \mathrm{W}\right)$, Arkansas. Results from the studies on the fallout from the first through the 14th Chinese nuclear tests have been reported earlier (see, for example, KURODA et al., 1965a, b; BECK and KURODA, 1966; COOPER and KuroDA, 1966; REYNOLDS et al., 1967; SwINDLE and KURODA, 1969; COOPER et al. 1970; NOYCE et al., 1971, 1973; MoORE et al., 1973; KuRODA et al., 1978).

The most recent nuclear explosion, which was reported as the 25th test, occurred on 16 October 1980, and U.S. Energy Department officials put the size of the explosion at between 200,000 and a million tons of TNT. We have carried out radiochemical measurements of the concentrations of ${ }^{89} \mathrm{Sr}$ and ${ }^{90} \mathrm{Sr}$ in a total of 117 samples of individual rain and snow collected at Fayetteville, Arkansas, during the period between September 1979 and August 1981. The pattern of variation of the ${ }^{89} \mathrm{Sr} /{ }^{90} \mathrm{Sr}$ ratio in rain observed at Fayetteville, Arkansas, after the 25 th Chinese test was quite unusual and different from those observed after the previous Chinese tests.

A preliminary note on the unusual pattern of variation of the ${ }^{89} \mathrm{Sr} /{ }^{90} \mathrm{Sr}$ ratio in rain after the 25th Chinese test, in comparison with the patterns of variations of the ${ }^{89} \mathrm{Sr} /{ }^{90} \mathrm{Sr}$ ratio in rain which were observed after the 15 th through 24th Chinese tests, was recently reported by BuRCHFIELD et al. (1982). A detailed mathematical interpretation of the strontium isotope ratio data according to the general theory of radioactive fallout based on the two-box model of the atmosphere (KURODA, 1958) is presented here.

\section{EXPERIMENTAL}

Individual rain and snow samples were collected by a sampling system installed on the roof of the Chemistry Building of the University of Arkansas in Fayetteville, Arkansas. The strontium isotopes were radiochemically isolated from 8 to 20 liters of rain and snow, and exhaustively purified (Hodges, 1963). The sam- 
ples were counted on the Tracerlab BLB 50520S 'Omniguard Low Background Table Top Automatic Counting System. Each sample was counted for about one month and the total beta activity due to 50.52 -day ${ }^{89} \mathrm{Sr}, 29$-year ${ }^{90} \mathrm{Sr}$ and 64.0-hour ${ }^{90} \mathrm{Y}$ was observed. Yttrium-90 was then separated from the strontium sample and its activity was counted. The amounts of ${ }^{89} \mathrm{Sr}$ and ${ }^{90} \mathrm{Sr}$ in rainwater at the time of the rainfall was calculated from the counting data.

\section{RESUlTS AND DisCUSSION}

Table 1 shows a comparison of the average monthly concentrations $(\overline{\mathrm{C}})$ of ${ }^{90} \mathrm{Sr}$ in rain at Fayetteville, Arkansas, for the period 19591961 and 1979-1981. The ${ }^{90} \mathrm{Sr}$ data for the former period was taken from the report by Kuroda et al. (1962). The values of $\overline{\mathrm{C}}$ were calculated from the equation

$$
\overline{\mathrm{C}}=\Sigma F / \Sigma R
$$

where $\Sigma F$ is the total amount of ${ }^{90} \mathrm{Sr}$ (in pCi per square meter) transported by rain during the period of a month and $\Sigma R$ is the total rainfall (in millimeters) during the same period. The concentrations of ${ }^{90} \mathrm{Sr}$ in rain during the period between November 1979 and December 1980 were much lower than those during the period 1959-1960, but the effect of the 25th Chinese test of 16 October 1980 was felt during the spring of 1981 and the value of $\overline{\mathrm{C}}$ for the month of March 1981 (2.13 pCi/l) was comparable to that for the month of March 1961 (3.4 pCi/l).

Figure 1 shows the variation of the ${ }^{90} \mathrm{Sr}$ concentrations in individual samples of rain and snow at Fayetteville, Arkansas, for the period between April 1979 and May 1981. The ${ }^{90} \mathrm{Sr}$ data for the period between April and August 1979 obtained in our laboratories by STEVENS (1981) are also plotted here. The short-lived isotope ${ }^{89} \mathrm{Sr}$ was present in a total of 41 samples of rain and snow collected after the 16 October 1980 nuclear explosion. Figure 2 shows the variation of the ${ }^{89} \mathrm{Sr} /{ }^{90} \mathrm{Sr}$ ratio in rain caused by the Chinese nuclear explosion.

Aside from the 16 October 1980 Chinese

Table 1. A comparison of the average monthly concentrations $(\bar{C})$ of ${ }^{90} \mathrm{Sr}$ in rain at Fayetteville, Arkansas, for the periods 1959-1961 and 1979-1981.

\begin{tabular}{|c|c|c|c|}
\hline \multicolumn{2}{|c|}{$1959-1961$} & \multicolumn{2}{|c|}{$1979-1981$} \\
\hline Month & $\overline{\mathrm{C}}(\mathrm{pCi} / \ell)$ & Month & $\overline{\mathrm{C}}(\mathrm{pCi} / \mathrm{l})$ \\
\hline 1959 & & 79 & \\
\hline November & 0.3 & November & .09 \\
\hline December & 2.36 & December & .09 \\
\hline 1960 & & 80 & \\
\hline January & 1.04 & January & .16 \\
\hline February & 3.79 & February & .11 \\
\hline March & 2.98 & March & .20 \\
\hline April & 3.23 & April & .22 \\
\hline May & 1.92 & May & .13 \\
\hline June & 3.35 & June & .12 \\
\hline July & 0.75 & July & .20 \\
\hline August & 1.13 & August & .08 \\
\hline September & 0.75 & September & .04 \\
\hline October & 0.4 & October & .04 \\
\hline November & 1.9 & November & .12 \\
\hline December & 1.3 & December & .09 \\
\hline 1961 & & 81 & \\
\hline January & 3.8 & January & .26 \\
\hline February & 2.5 & February & .18 \\
\hline March & 3.4 & March & 2.13 \\
\hline April & 5.1 & April & .65 \\
\hline May & 4.0 & May & .60 \\
\hline
\end{tabular}


nuclear explosion, a number of events which could have affected the inventories of man-made and natural radionuclides in the atmosphere occurred during the two year period 19791981: (1) the Three-Mile Island accident of 30 March 1979, (2) the unconfirmed report of a nuclear explosion in the Atlantic off the coast of South Africa (22 September 1979), (3) the 18 May 1980 eruption of Mount St. Helens and (4) uranium fallout from the burn-up of the nuclearpowered Soviet satellite Cosmos-954, which, according to SAKURAGI et al. (1981), was detected in several rain samples collected at Fayetteville, Arkansas, during the months of April and May 1980 at about the same time of the major eruption of Mount St. Helens. The fact that ${ }^{89} \mathrm{Sr}$ was not detected in any of the samples of rain and snow collected at Fayetteville during the period between April 1979 and September 1980 indicates that the amount of fission products injected into the atmosphere by any of the above-mentioned events was negligibly small.

The appearance of ${ }^{89} \mathrm{Sr}$ was first noted in the rain of 23-24 October 1980, one week after the 16 October 1980 nuclear explosion (see Fig. 2). The ${ }^{89} \mathrm{Sr} /{ }^{90} \mathrm{Sr}$ ratio in rain decreased rapidly along the line $P Q$ in Fig. 2, where the point $P=$ 170 represents the production ratio of ${ }^{89} \mathrm{Sr} /{ }^{90} \mathrm{Sr}$ $(\mathrm{Ci} / \mathrm{Ci})$ in thermal neutron-induced fission of ${ }^{235} \mathrm{U}$. A sharp increase in the ${ }^{89} \mathrm{Sr} /{ }^{90} \mathrm{Sr}$ ratio in rain occurred on 14 November 1980, approxi-

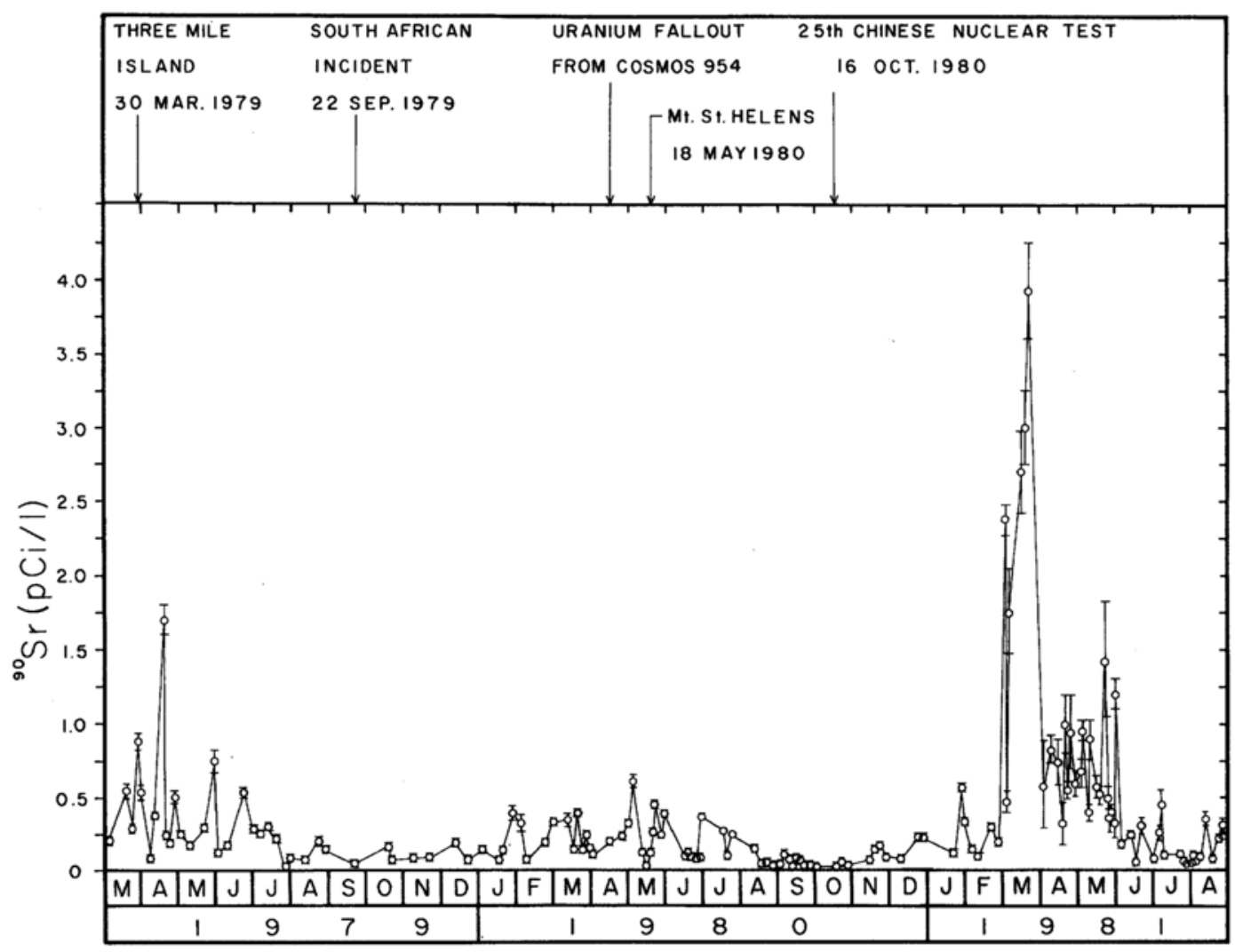

Fig. 1. Variation of the ${ }^{90} \mathrm{Sr}$ concentration (o) in rain at Fayetteville, Arkansas, during the period between April 1979 and June 1981. The ${ }^{90} \mathrm{Sr}$ data for the period April through August 1979 were taken from the thesis of STAN STEVENS (1981). 
mately a month after the time of the nuclear explosion. The ${ }^{89} \mathrm{Sr} /{ }^{90} \mathrm{Sr}$ ratio in rain then declined along the line $P R$, until toward the end of December 1980, when it started to increase gradually and approached the line $P S$ asymptotically, as shown in Fig. 2.

A complicated pattern of variation of the
${ }^{89} \mathrm{Sr} /{ }^{90} \mathrm{Sr}$ ratio in rain, such as shown in Fig. 2, creates an impression that perhaps more than one nuclear explosion might have occurred, but it seems that the strontium isotope ratio data shown in Fig. 2 can be explained in terms of the general theory of radioactive fallout based on the two-box model of the atmosphere (KURODA,

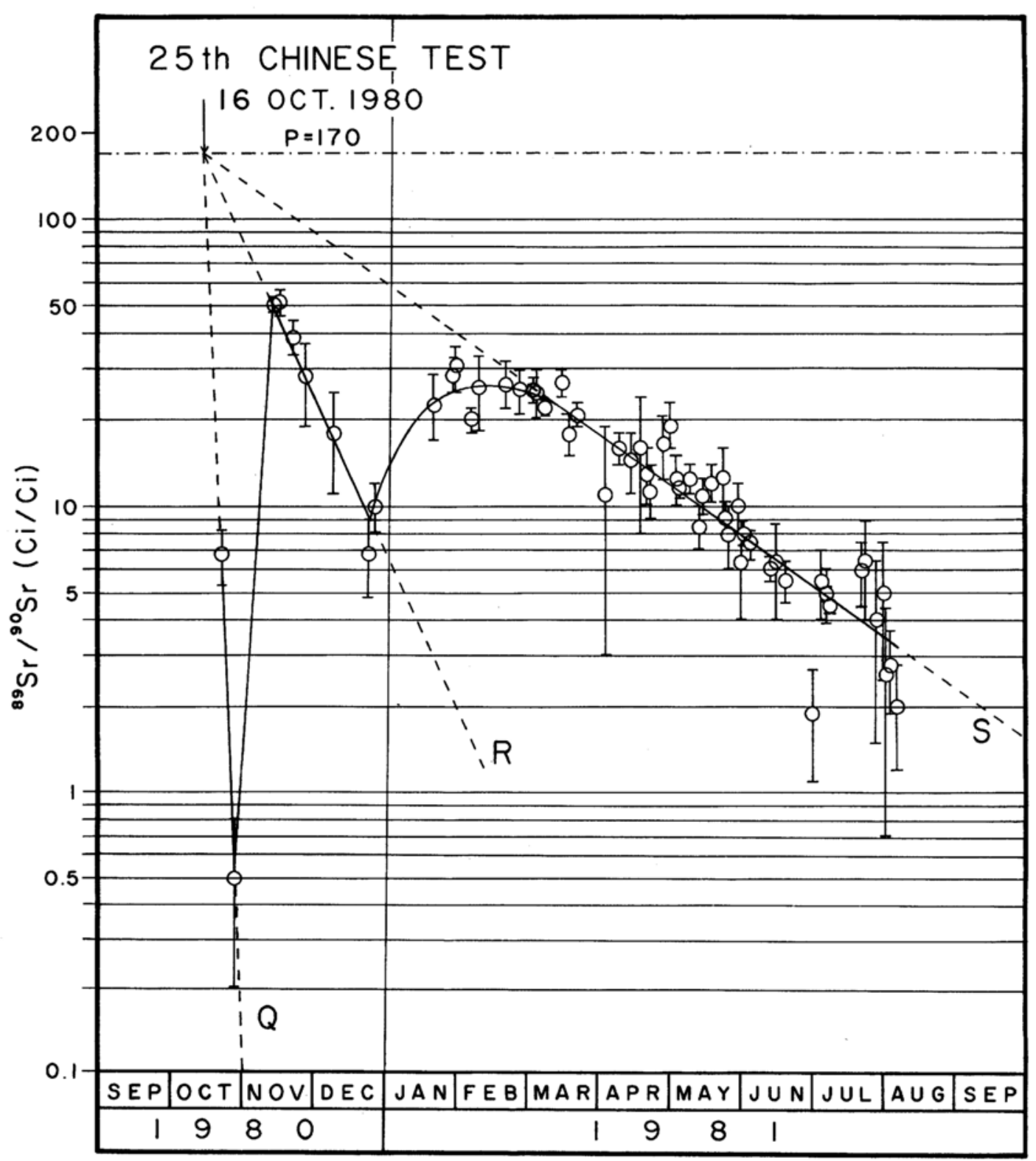

Fig. 2. Variations of the ${ }^{89} \mathrm{Sr} /{ }^{90} \mathrm{Sr}$ ratio in rain after the 25 th Chinese test of 16 October 1980. 
1958), taking into consideration the fact that the nuclear debris released into the atmosphere at Lop Nor, China, travels eastward and circles the world a number of times (KuRODA et al., 1965b). The first 'wave' of the fresh debris produced at Lop Nor, China, must have reached Fayetteville about a week after the nuclear explosion causing the first appearance of ${ }^{89} \mathrm{Sr}$ in the 23-24 October 1980 rain. After circling the world in about three weeks, the second wave of fresh debris reached Fayetteville for the second time on November 14, 1980.

The lines $P Q$ and $P R$ in Fig. 2 are given by the equations (2) and (3), respectively:

$$
\begin{aligned}
& \left({ }^{89} \mathrm{Sr} /{ }^{90} \mathrm{Sr}\right)=170 \exp (-0.447 t) \\
& \left({ }^{89} \mathrm{Sr} /{ }^{90} \mathrm{Sr}\right)=170 \exp (-0.0425 t)
\end{aligned}
$$

where $t$ is the number of days elapsed between the data of the nuclear explosion (16 October $1980)$ and the data of rainfall. tion

The curve ( $R S$ in Fig. 2 is given by the equa-

$$
\begin{aligned}
\left({ }^{89} \mathrm{Sr} /{ }^{90} \mathrm{Sr}\right)= & -55 \exp \left(-0.0387 t^{\prime}\right) \\
& +65 \exp \left(-0.0137 t^{\prime}\right)
\end{aligned}
$$

where $t^{\prime}$ is the number of days elapsed between an arbitrarily chosen date of 24 December 1980 and the date of rainfall.

These equations can be considered to be special cases of a general equation, which gives the ${ }^{89} \mathrm{Sr} /{ }^{90} \mathrm{Sr}$ ratio in atmospheric precipitation as a function of the time elapsed since a nuclear explosion. According to the general theory of radioactive fallout based on the two-box model of the atmosphere (KURODA, 1958), the atmosphere consists of two compartments 1 and 2 and radioactive isotopes $\mathrm{A}$ and $\mathrm{B}$ are transferred from the upper compartment 1 to the lower compartment 2 at a rate denoted as $\lambda_{1}$ and removed from the latter at a rate denoted as $\lambda_{2}$. The removal rates $\lambda_{1}$ and $\lambda_{2}$ may vary seasonally, but let us assume for the time being that they are constants and $\lambda_{1} \ll \lambda_{2}$. If we are dealing with an event which is taking place with a time-scale of a few days to a month or two, the upper and the lower compartments may be considered to be representing the stratosphere and the troposphere, respectively, and hence $\lambda_{1}$ and $\lambda_{2}$ may represent the removal rates from the stratosphere and the troposphere, respectively. If we are dealing with an event which is taking place with a time scale of a few months to a year or more, the upper and the lower compartments may be considered to be representing the upper and the lower stratosphere, respectively.

Let us now assume that the fallout processes from compartments 1 and 2 occur in the following manner:

$$
-\mathrm{d}\left(\mathrm{A}_{1}\right) / \mathrm{dt}=\left(\lambda_{1}+\lambda_{\mathrm{A}}\right) \mathrm{A}_{1}
$$

and

$$
-\mathrm{d}\left(\mathrm{A}_{2}\right) / \mathrm{dt}=-\lambda_{1} \mathrm{~A}_{1}+\left(\lambda_{2}+\lambda_{\mathrm{A}}\right) \mathrm{A}_{2}
$$

where $A_{1}$ and $A_{2}$ are the inventories of an isotope $\mathrm{A}$, say ${ }^{90} \mathrm{Sr}$, in compartments 1 and 2 , respectively; $\lambda_{\mathrm{A}}$ is the decay constant; and $\lambda_{1}$ and $\lambda_{2}$ are the rate constants for the removal processes from compartments 1 and 2, respectively.

From equations (5) and (6), we have

$$
\begin{gathered}
A_{2, t}=\frac{\lambda_{1}}{\lambda_{2}-\lambda_{1}} \cdot A_{1,0} \cdot\left[\exp -\left(\lambda_{1}-\lambda_{A}\right) t-\right. \\
\left.\exp -\left(\lambda_{2}-\lambda_{A}\right) t\right]+A_{2,0} \\
\exp -\left(\lambda_{2}-\lambda_{A}\right) t
\end{gathered}
$$

where $A_{1,0}$ and $A_{2,0}$ are the inventories of $A$ in compartments 1 and 2 , respectively, at $t=$ $\mathrm{O}$ and $\mathrm{A}_{2, t}$ is the inventory of $\mathrm{A}$ in compartment 2 at time $t$.

The same expression as (7) can be written for another isotope $\mathrm{B}$, say ${ }^{89} \mathrm{Sr}$, if $\lambda_{1}$ and $\lambda_{2}$ can be considered to be common for both isotopes $\mathrm{A}$ and $\mathrm{B}$, and the ratio of the inventories of $\mathrm{A}$ and $\mathrm{B}$ in the lower compartment 2 as a function of time can be shown to be given by the general equation 


$$
\begin{aligned}
\left(\frac{B_{2, t}}{A_{2, t}}\right)= & \frac{\Phi}{\exp \left(\lambda_{2}-\lambda_{1}\right) t-1+\Phi}\left[\left(\frac{B_{2,0}}{A_{2,0}}\right)\right. \\
& \left.-\left(\frac{B_{1,0}}{A_{1,0}}\right)\right] \cdot \exp -\left(\lambda_{B}-\lambda_{A}\right) t \\
& +\left(\frac{B_{1,0}}{A_{1,0}}\right) \cdot \exp -\left(\lambda_{B}-\lambda_{A}\right) t
\end{aligned}
$$

where

$$
\Phi=\frac{\lambda_{2}-\lambda_{1}}{\lambda_{1}} \cdot \frac{A_{2,0}}{A_{1,0}}
$$

The value of $\Phi$ is dependent upon the type of nuclear explosion which occurred at time $t_{0}$. Suppose that the previous nuclear explosion had occurred a long time ago and the following steady-state relationship had been established between the amounts of the isotope $\mathrm{A}$ in compartments 1 and 2:

$$
\frac{\lambda_{2}-\lambda_{1}}{\lambda_{1}} \cdot \frac{\mathrm{A}_{2}^{\prime}}{\mathrm{A}_{1}^{\prime}}=1
$$

If $A_{1}^{\prime \prime}$ and $A_{2}^{\prime \prime}$ curies of the isotope $A$ were injected into the compartments 1 and 2, respectively, at time $t_{o}$, we have the relationship

$$
\mathrm{A}_{1}^{\prime}+\mathrm{A}_{1}^{\prime \prime}=\mathrm{A}_{1,0}
$$

and

$$
\mathrm{A}_{2}^{\prime}+\mathrm{A}_{2}^{\prime \prime}=\mathrm{A}_{2,0}
$$

From equations (9)-(12), we obtain the relationship

$$
\Phi=\frac{\lambda_{2}-\lambda_{1}}{\lambda_{1}} \cdot \frac{A_{2,0}}{A_{1,0}}=\frac{1+\left(\frac{A_{2}^{\prime \prime}}{A_{2}^{\prime}}\right)}{1+\left(\frac{A_{1}^{\prime \prime}}{A_{1}^{\prime}}\right)}
$$

Equations (2) and (3) which give the lines $P Q$ and $P R$ in Fig. 2 can be obtained from the general equation (8) by making the following substitutions: $\lambda_{1}=O ; \lambda_{A}=O ; \lambda_{B}=0.0137$ $\left(\right.$ day $\left.^{-1}\right) ; \Phi=1 ;\left(\mathrm{B}_{1,0} / \mathrm{A}_{1,0}\right)=\mathrm{O} ;\left(\mathrm{B}_{2,0} / \mathrm{A}_{2, \mathrm{O}}\right)=$ $P=170$; and $\lambda_{2}=0.433\left(\right.$ day $\left.^{-1}\right)$ and $\lambda_{2}=$ $0.0288\left(\right.$ day $\left.^{-1}\right)$, which lead to equations (2) and (3), respectively.

The removal rate $\lambda_{2}$ from the lower compartment (troposphere) is obviously much greater than the removal rate $\lambda_{1}$ from the upper compartment (stratosphere) and hence it can be assumed that $\lambda_{1}=0$. The half-life of the radioisotope $\mathrm{A}\left({ }^{90} \mathrm{Sr}\right)$ is much longer than that of $\mathrm{B}$ $\left({ }^{89} \mathrm{Sr}\right)$ and hence $\lambda_{A}$ can be regarded as equal to zero. Equation (13) shows that $\Phi$ is equal to unity only when

$$
\frac{\mathrm{A}_{1}^{\prime \prime}}{\mathrm{A}_{1}^{\prime}}=\frac{\mathrm{A}_{2}^{\prime \prime}}{\mathrm{A}_{2}^{\prime}}
$$

which means that the inventories of ${ }^{90} \mathrm{Sr}$ in compartment 1 (stratosphere) and in compartment 2 (troposphere) were affected by the 16 October 1980 nuclear explosion in approximately equal proportions, which, in turn, means that very large quantities of the fresh debris relative to the old debirs were injected both into the stratosphere and the troposphere.

The reason why equations (2) and (3) can be obtained from the general equation (8) by introducing $\left(\mathrm{B}_{1,0} / \mathrm{A}_{1,0}\right)=\mathrm{O}$ may be attributed to the fact that it takes several weeks before the fresh debris injected into the stratosphere becomes uniformly mixed, just as is the case for the debris injected into the troposphere. During the period between the middle of October and the middle of December 1980, a stratospheric air mass which was free of fresh nuclear debris may have been located over Fayetteville, Arkansas. In other words, a large quantity of fresh debris injected into the stratosphere was simply not 'visible' from the ground level until after the middle of December 1980.

The values of $\lambda_{2}=0.433\left(\mathrm{day}^{-1}\right)$ and $\lambda_{2}=$ $0.0288\left(\right.$ day $\left.^{-1}\right)$, can be thus obtained from the ${ }^{90} \mathrm{Sr}$ atoms found in the first and second 'waves' of fresh debris and correspond to the mean residence times $\left(\tau_{2}=1 / \lambda_{2}\right)$ of 2.3 days and 34.7 days, respectively. The difference in the values of mean residence times of the ${ }^{90} \mathrm{Sr}$ atoms in the fresh debris which arrived at Fayetteville for the first and the second time may be at- 
tributable to the difference in the particle size distribution.

BAUGH et al. (1967) have reported that the average diameter (D) of particles which arrived at Fayetteville during the month of May in the first 'wave' of fresh debris from the third Chinese test of 9 May 1966 was 4 microns, while those of the particles which arrived during the months of June and July 1966 were about 2 to 3 microns. On the night of 23 March 1972, five days after the 14th Chinese test of 18 March 1972, MOore et al. (1973) found an exceptionally large 34-micron-size particle in the first wave of nuclear debris which arrived at Fayetteville from Lop Nor, China.

Equation (4), which gives the curve $R S$ in Fig. 2, can be obtained from the general equation (8) by making the following substitutions: $\left(\mathrm{B}_{1,0} / \mathrm{A}_{1,0}\right)=65$ (the ${ }^{89} \mathrm{Sr} /{ }^{90} \mathrm{Sr}$ ratio in the stratosphere on 26 December 1980); $\left(\mathrm{B}_{2,0} /\right.$ $\mathrm{A}_{2, \mathrm{O}}$ ) $=10.0$ (observed ${ }^{89} \mathrm{Sr} /{ }^{90} \mathrm{Sr}$ ratio in rain collected on 26 December 1980); $\lambda_{1}=0 ; \lambda_{A}=$ $\mathrm{O} ; \lambda_{\mathrm{B}}=0.0137\left(\mathrm{day}^{-1}\right) ; \Phi=1 ;$ and $\lambda_{2}=0.025$ $\left(\right.$ day $\left.^{-1}\right)$, which corresponds to a value of $\tau_{R}=$ 40 days for the mean residence time of ${ }^{90} \mathrm{Sr}$ in the troposphere.

The pattern of variation of the ${ }^{89} \mathrm{Sr} /{ }^{90} \mathrm{Sr}$ ratio in rain after December 1980, which is illustrated by the curve $R S$ in Fig. 2, may be interpreted in the following manner: (a) a large quantity of fresh nuclear debris injected into the stratosphere by the 16 October 1980 nuclear explosion was not 'visible' until December 1980, because of the fact that it takes several weeks before the fresh debris injected into the stratosphere becomes more or less uniformly mixed; (b) by the time the stratospheric debris became 'visible' in rain during December 1980 , the ${ }^{89} \mathrm{Sr} /$ ${ }^{90} \mathrm{Sr}$ ratio in the stratosphere, $\left(\mathrm{B}_{1,0} / \mathrm{A}_{1,0}\right)$, had decreased to a value of about 65 from the initial value of 170 , because of the decay of the short-lived isotope ${ }^{89} \mathrm{Sr}$; (c) the ${ }^{89} \mathrm{Sr} /{ }^{90} \mathrm{Sr}$ ratio in the troposphere in December 1980 was equal to about 10 , which is the observed ${ }^{89} \mathrm{Sr} /{ }^{90} \mathrm{Sr}$ ratio in the 26 December 1980 rain; and (d) the ratio of the stratospheric debris to the tropospheric debris in the samples of rain and snow collected at Fayetteville increased steadily after December 1980 and by March 1981 the atoms of ${ }^{89} \mathrm{Sr}$ and ${ }^{90} \mathrm{Sr}$ found in atmospheric precipitation became purely of those initially injected into the stratosphere.

Ackinowledgment-This investigation was supported by the National Science Foundation under grant ATM 7819965.

\section{REFERENCES}

Baugh, J. O., Yoshikawa, K. and Kuroda, P. K. (1967) Single fallout particles and zirconium-95 from the Chinese nuclear explosion of 9 may 1966. Science 155, 1405-1407.

BECK, J. N. and KURODA, P. K. (1966) Radiostrontium fallout from the nuclear explosion of October 16, 1964. J. Geophys. Res. 71, 2451-2456.

BurchField, L. A., Stevens, S., InN, K. G. W., SUMERLIN, N. G. and KURODA, P. K. (1982) Atmospheric injections of nuclear debris: Strontium 89 and 90 from Chinese weapons tests. J. Geophys. Res. 87, 7273-7278.

COOPER, W. A. and KurodA, P. K. (1966) Global circulation of nuclear debris from the May 14, 1965, nuclear explosion. J. Geophys. Res. 71, 5471-5473. COOPER, W. W., BECK, J. N., CHEN, T. S. and KURODA, P. K. (1970) Radioactive strontium and barium fallout. Health Phys. 19, 625-632.

HODGES, H. L. (1963) Radiochemical determination of ${ }^{89} \mathrm{Sr},{ }^{90} \mathrm{Sr}$, and ${ }^{140} \mathrm{Ba}$ in nuclear debris, Annual Progress Report to the U. S. At. Energy Comm. Contract At-140-1)-2529 (Dec. 31), 32-109.

KURODA, P. K. (1958) On the stratospheric ${ }^{90} \mathrm{Sr}$ fallout. Argonne National Laboratory Report ANL$5920,1-40$.

KURODA, P. K., HODGES, H. L., FRY, L. M. and MOORE, H. E. (1962) Stratospheric residence time of strontium-90. Science 137, 15-17.

KURODA, P. K., PALMER, D. B., ATTREP, M. JR., BECK, J. N., Ganapathy, R., SABU, D. D. and RAO, M. N. (1965a) Fallout from the nuclear explosion of 16 October 1964. Since 142, 1248-1286.

KuRODA, P. K., MIYAKE, Y. and NEMOTO, J. (1965b) Strontium isotopes: Global circulation after the Chinese nuclear explosion of 14 May 1965. Science 150, 1289-1290.

KuRODA, P. K., DANIEL, P. Y., NeVISSI, A., BECK, J. N. and MEASON, J. L. (1978) Atmospheric residence times of strontium-90 and lead-210. $J$. Radioanal. Chem. 43, 443-450.

MOORE, D. T., BECK, J. N., Miller, D. K. and 
KURODA, P. K. (1973) Radioactive hot particles from the recent Chinese nuclear weapons tests. $J$. Geophys. Res. 78, 7039-7050.

NOYCE, J. R., CHEN, T. S., MOORE, D. T., BECK, J. N. and KURODA, P. K. (1971) Temporal distributions of radioactivity and ${ }^{89} \mathrm{Sr} /{ }^{90} \mathrm{Sr}$ ratios during rainstorms. J. Geophys. Res. 76, 646-656.

NOYCE, J. R., MOORE, D. T., SHERWOOD, J. D. DANIEL, P. Y., BECK, J. N. and KURODA, P. K. (1973) Fallout from nuclear weapons testing and interhemispheric transport of nuclear debris. Health Phys. 25, 109-114.

REYNOLDS, M. A., SWINDLE, D. L., WRIGHT, R. J. and KURODA, P. K. (1967) Fallout from the Chinese nuclear explosion of 17 June 1967. Science 158, 1692-1693.

SakuRagi, Y., MEason, J. L. and KuRoda, P. K. (1981) Uranium and plutonium isotopes in the atmosphere. Submitted to J. Geophys. Res.

STEVENS, S. W. (1981) Recent injections of nuclear debris in the atmosphere, Ph. D. Dissertation, University of Arkansas, 1-125.

SWINDLE, D. L. and KuROdA, P. K. (1969) Variation of the ${ }^{89} \mathrm{Sr} /{ }^{90} \mathrm{Sr}$ ratio in rain caused by the Chinese nuclear explosion of December 28, 1966, and June 17, 1967. J. Geophys. Res. 74, 21362140 . 